Copyright (C) 2021 by Cherkas Global University

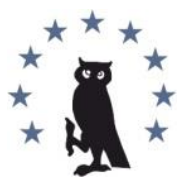

Published in the USA

Voennyi Sbornik

Has been issued since 1858 .

E-ISSN: $2409-1707$

2021. 9(2): 105-120

DOI: $10.13187 /$ vs.2021.2.105

https://vs.cherkasgu.press

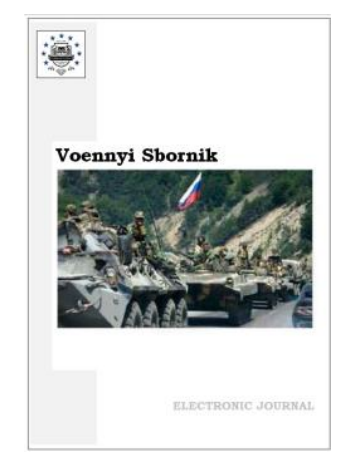

\title{
The Detachments of the People's Militia on the Territory of Greater Sochi during the Great Patriotic War (July 1941 - August 1942)
}

Anvar M. Mamadaliev a, b, Konstantin V. Taran a , b *

a Cherkas Global University, Washington, USA

b Volgograd State University, Volgograd, Russian Federation

\begin{abstract}
This article discusses the organization and activities of the people's militia units created in July 1941 on the territory of Greater Sochi during the Great Patriotic War. They operated until August 1942, after which the militia units with their property were transferred to the fighter battalions. During the period of activity in the people's militia units, the fighters underwent military training, carried out the guard duty.

There were used as sources the archival materials of the Center for Documentation of the Modern History of the Krasnodar Kray and the municipal government institution "Archive of Sochi", the collections of archival documents. In addition, the articles and publications of russian researchers, memoirs of veterans were involved.

The author comes to the conclusion that the activities of the people's militia units were aimed at carrying out the guard duty for the protection of strategic objects. Military and special disciplines were also trained, i.e. the people's militia units were the personnel reserve of the Red Army.

Keywords: people's militia, military training, municipal and district committees of the AllUnion Communist Party (Bolsheviks), City Executive Committee.

\section{1. Введение}

После вторжения войск вермахта 22 июня 1941 г. на территорию СССР в населенных пунктах Краснодарского края было введено военное положение и созданы отряды народного ополчения. В Большом Сочи они были сформированы в городе Сочи и в Адлерском районе Краснодарского края, в районном центре Шапсугского района с. Лазаревское - не создавались.

В данной статье рассматриваются создание и деятельность отрядов народного ополчения города Сочи и Адлерского района (июль 1941 г. - август 1942 г.), в которых бойцы проходили военное и специальное обучение, несли караульно-постовую службу. В указанный период из отрядов народного ополчения систематически призывались бойцы в ряды РККА5, истребительные батальоны и отделы НКВД6.
\end{abstract}

\footnotetext{
* Corresponding author

E-mail addresses: taran.constantin@yandex.ru (K.V. Taran), anvarm@mail.ru (A.M. Mamadaliev)

5 РККА - Рабоче-крестьянская Красная армия.

${ }^{6}$ НКВД - Народный комиссариат внутренних дел.
} 


\section{2. Материалы и методы}

В качестве материалов применялся комплекс разнообразных источников. В первую очередь из Центра документации новейшей истории Краснодарского края (ЦДНИКК) и муниципального казенного учреждения города Сочи «Сочинский городской архив» (МКУ «Архив г. Сочи»).

Дополнительно были задействованы воспоминания ветеранов войны (Солдатские мемуары..., 1998), сборники архивных документов (Кубань..., 1965; Кубань..., 200о), справочная литература (Основные..., 1986), а также монографии, статьи и публикации российских исследователей (Артюхов, 1995; Артюхов, 2000; Киселев, 2017; Куликов, 2009; Кучерова, 2005; Taran, 2020; Черкасов, 2008a; Черкасов, 2008b; Черкасов, 2008c).

В качестве методов исследования использовались как общенаучные, так и специальные исторические. Основным в данной работе стал историко-генетический метод, который применялся для анализа причинно-следственных связей между действиями отдельных лиц и событиями, что позволило нам приблизиться к воспроизведению исторической ситуации с высокой степенью объективности. Другим важнейшим методом стал историко-системный, позволивший исследовать особенности организации народного ополчения в неразрывной связи с социальной, экономической и политической обстановкой.

Применялись также историко-сравнительный (для сопоставления отрядов народного ополчения с другими войсковыми подразделениями собственных вооруженных сил) и историко-типологический методы (для выделения типов подразделений и служб народного ополчения и регулярных частей РККА, классификации личного состава и пр.).

Из нетрадиционных исторических методов исследования были применены историкостатистический (количественный анализ численности подразделений народного ополчения), метод исторической семиотики (анализ и «расшифровка» используемых в работе военно-исторических и прочих аббревиатур и др.).

Среди используемых в работе общенаучных методов применялись научный анализ, синтез, а также обобщение, категоризация и классификация.

В основе исследования лежит принцип историзма, который позволил сделать комплексный объективный анализ архивных материалов и иных источников, относящихся к созданию и деятельности отрядов народного ополчения в городе Сочи и Адлерском районе. Кроме того, использовались принципы объективности, системности, хронологизма и опоры на исторические источники.

\section{3. Обсуждение}

В основном историография исследования создания и деятельности отрядов народного ополчения, сформированных на территории Большого Сочи в годы Великой Отечественной войны, относится к российскому периоду.

Создание штабов и отрядов народного ополчения в Краснодарском крае, а также документы и решения, регламентирующие их деятельность, опубликованы в сборнике рассекреченных материалов (Кубань..., 2000).

Нами рассмотрены формирование, структура и деятельность сочинского отряда народного ополчения (Мамадалиев, 2007), а также в научно-популярном издании (Таран, 2019) уделено внимание созданию и обучению ополченцев военным и специальным дисциплинам.

\section{4. Результаты}

22 июня 1941 г. без объявления войны германские войска вторглись на территорию Советского Союза. Указом Президиума Верховного Совета СССР в Краснодарском крае и в других отдельных местностях в соответствии со ст. 49 п. «П» Конституции СССР в интересах обороны страны и для обеспечения общественного порядка и государственной безопасности было объявлено военное положение (Ведомости, 1941; Вестник архива, 2010: 27-31).

24 июня 1941 г. в Сочинском горкоме ВКП(б)7 состоялось специальное совещание «О проведении мероприятий по г. Сочи в связи с введением военного положения».

\footnotetext{
7 Горком ВКП(б) - Сочинский городской комитет Всесоюзной коммунистической партии
} (большевиков). 
Военному командованию предлагалось выделить двух-трех командиров в помощь городским организациям для создания боевых дружин из коммунистов, комсомольцев, членов Осоавиахима 8 и других добровольцев (ЦДНИКК. Ф. 558. Оп. 1. Д. 136-А. Л. 1-3).

В соседнем Адлерском районе 26 июня 1941 г. было проведено бюро партийного актива, на котором было решено для обороны рабочего поселка Адлер и его района создать боевую дружину из партийного актива. Заведующему военным отделом Шихову было поручено предоставить в бюро райкома ВКП(б)9 персональный список для утверждения состава боевой дружины (ЦДНИКК. Ф. 508. Оп. 1. Д. 65. Л. 177).

Следует отметить состояние административно-территориального деления в указанный период. В состав Адлерского района Краснодарского края входили следующие сельские советы: Аибгский, Ахштырский Волковский, Ермоловский, Красновольский, Краснополянский, Леснянский, Липниковский, Лооский, Нижнешиловский, Раздольский, Солохаульский, Кудепстинский. Рабочий поселок Адлер являлся административным центром района (Основные..., 1986: 118).

Фактически Адлерский район был растянут на протяжении более 80 км вдоль берега Черного моря, за исключением территории города Сочи. При этом сельские населенные пункты Адлерского района были расположены не только на берегу моря, но и в горной местности на южной стороне Главного Кавказского хребта, что не способствовало быстрому сообщению с районным центром. В состав города Сочи входили курортные поселки Мацеста и Хоста, а также Пластунский и Навагинский сельские советы (Основные..., 1986: 117, 132).

Военный Совет $\mathrm{CKBO}^{10} 6$ июля 1941 г. направил директиву крайкому ВКП(б) ${ }^{11}$ о создании в Краснодарском крае отрядов народного ополчения для усиления частей РККА, оборонявших территорию Северного Кавказа от возможного вторжения войск гитлеровской коалиции. Намечалось укомплектовать эти отряды рабочими, служащими и интеллигенцией, независимо от возраста, умеющими владеть оружием, а также сформировать пять стрелковых полков в Краснодаре, Туапсе, Новороссийске, Майкопе и Армавире и четыре стрелковых батальона в Анапе, Сочи, Хосте и Адлере. Соответствующее указание последовало от крайкома ВКП(б) городским и районным комитетам партии Краснодарского края. Уже через два дня в Краснодар стала поступать информация с мест об организации отрядов народного ополчения (Кубань..., 2000: 34).

По распоряжению Сочинского горкома ВКП(б) 12 июля 1941 г. из добровольцев рабочих, служащих городских предприятий и учреждений - был сформирован отряд народного ополчения по схеме подразделений РККА, т.е. был создан полк, состоящий из 3 батальонов, по 3 роты в каждом.

На 14 июля 1941 г. командно-политический и административно-хозяйственный состав отряда в количестве 144 человек был следующим: командир отряда, комиссар, начальник штаба, помощник начальника штаба, помощник начальника отряда $\mathrm{MTO}^{12}$, военный инженер, старший санитарный врач, начальник МTO, начальник боепитания, начальник оружейной мастерской (оружейный каптенармус), вещевой каптенармус, фуражир, делопроизводитель по строевой части, делопроизводитель МТО, старший писарь по строевой части, старший писарь по МТО, писарь по строевой части, писарь по МТО, машинистка, командир взвода особого назначения, начальник химической службы, начальник связи, начальник санитарной службы, начальник автомотоколонны (всего 24 человека), 3 командира батальонов, 9 командиров рот, 27 командиров взводов и командиров отделений - 81 .

Всего в отряде числилось 1339 ополченцев, из которых 1236 мужчин и 193 женщины, в том числе 167 рабочих и 722 служащих, 267 членов и кандидатов ВКП(б), 175 членов

\footnotetext{
8 Осоавиахим - общество содействия обороне, авиационному и химическому строительству (19271948 гг.).

9 Райком ВКП(б) - Адлерский районный комитет Всесоюзной коммунистической партии (большевиков).

10 СКВО - Северо-Кавказский военный округ.

11 Крайком ВКП(б) - Краснодарский краевой комитет Всесоюзной коммунистической партии (большевиков).

12 МТО - материально-техническое обеспечение.
} 
ВЛКСМ, 514 служивших в РККА и участников гражданской войны, 825 человек не имели военной подготовки и боевого опыта (ЦДНИКК. Ф. 558. Оп. 1. Д. 161. Л. 1-2).

При отряде народного ополчения с 14 июля были организованы специальные службы - санитарная, химическая и связи, которые приступили к проведению занятий по имевшимся учебным программам.

Санитарная служба состояла из 42 человек, было проведено 38 факультативных занятий, кроме этого организовано 5 санитарно-тактических занятий и походов в полевых условиях. Посещаемость бойцов составила 80-90 \%. По окончании учебной 90-часовой программы были проведены зачеты, по знанию санитарной службы 40 \% бойцов получили оценки «отлично» и $60 \%$ - «хорошо». Все бойцы сдали зачет на знаки «Готов к санитарной обороне» 1 и 2 ступени и «Готов к противовоздушной и химической обороне». Кроме этого, бойцы санитарной службы изучали огнестрельное оружие: винтовку, пулемет, гранату и проводили стрелково-тактическую подготовку. В санитарной службе в наличии имелось 4 носилок, 4 сумки медикаментов и достаточное количество перевязочного материала (ЦДНИКК. Ф. 558. Оп. 1. Д. 161. Л. 3-4).

Химической службой в составе 21 человека было проведено 32 занятия по изучению химического дела и 5 практических занятий по определению зараженной местности, по ее дегазации. Занятия проводились в специальных костюмах. Посещаемость составила 9095 \%. По окончании 70-часовой программы был проведен зачет, по знанию химической службы ПВО 1345 \% бойцов получили оценки «отлично» и 55 \% - «хорошо». Все бойцы химической службы имели знак «Готов к противовоздушной и химической обороне», дополнительно изучали стрелковое военно-тактическое дело.

В службе связи числилось 15 человек. Было проведено 10 занятий по изучению следующих программ: возникновение и распространение звуковых колебаний; характеристика звуковых колебаний и звука; преобразование звуковых колебаний в электричестве; конструкция телефона и микрофона; принцип действия индукционной катушки; звонок переменного тока; батарея телефона аппарата; микрофонный аппарат; устранение повреждения проводов; испытание телефонных цепей; практическая проверка телефонного оборудования, телефонных аппаратов, полевого кабеля; установка центральной телефонной станции и двух телефонных пунктов (ЦДНИКК. Ф. 558. Оп. 1. Д. 161. Л. 4).

К обучению военно-специальных предметов в полку народного ополчения приступили также с 14 июля 1941 г. по программе, разработанной начальником Сочинского гарнизона и утвержденной штабом народного ополчения, включающей в себя необходимые знания для бойца-пехотинца РККА в современном бою. Программа состояла из 120 учебных часов строевой и стрелково-тактической подготовки (ЦДНИКК. Ф. 558. Оп. 1. Д. 161. Л. 6).

С июля 1941 г. отряд народного ополчения начал проводить военную учебу на материально-технической базе Осоавиахима, но этого было недостаточно. Командованием отряда были приняты меры к расширению материально-технической базы и укомплектованию учебными пособиями собственными средствами.

Силами сочинского ополчения был построен танк-макет на автомашине из 6-7 мм железа, что дало возможность бойцам на ходу забрасывать танк учебными гранатами, бутылками с бензином и керосином, а также бросать под него связки гранат. Такая постановка дела облегчила обучение бойцов народного ополчения и способствовала обучению гранатометчиков - бойцов-истребителей танков.

Также ополченцы самостоятельно изготовили 300 шт. малых и больших саперных лопат, пирамиды для оружия на 400 единиц, оборудовали склад для хранения оружия и огнеприпасов, сделали макеты ручных станковых пулеметов, учебными гранатами и деревянных ружей.

При помощи городского Осоавиахима отряд народного ополчения получал необходимые наглядные пособия. Для приобретения военной литературы отряду было выделено 5000 рублей. Кроме того, отряд располагал винтовкой германского образца (ЦДНИКК. Ф. 558. Оп. 1. Д. 161. Л. 6).

13 ПВО - противовоздушная оборона. 
В это время в Адлерском районе также происходило формирование отряда народного ополчения. На заседании партийного бюро Адлерского района, прошедшего 15 июля 1941 г., было решено обязать заведующего отделом пропаганды и агитации райкома ВКП(б) Сафонова немедленно организовать культурное обслуживание бойцов Адлерского гарнизона, истребительного батальона и народного ополчения (ЦДНИКК. Ф. 508. Оп. 1. Д. 66. Л. 50).

Члены Военного совета СКВО (командующий войсками СКВО генерал-лейтенант Рейтер, член Военного совета СКВО бригадный комиссар Пинчук, начальник штаба СКВО полковник Бармин) придавали огромное значение формированию отрядов народного ополчения в городах и районах Краснодарского края, ответственность за создание которых возлагалась на партийные организации края. Военным советом предлагалось в каждом полку народного ополчения иметь роту обслуживания, а в батальоне - взвод обслуживания, состоящий из связистов, врачей, санитаров, подносчиков патронов и хозяйственного обслуживания из расчета обеспечения полка-батальона в походных условиях.

Командирами полков, батальонов и рот следовало назначать лиц из командного состава запаса старших возрастов и частично из командного состава РККА. Командирами взводов и отделений - назначать наиболее расторопных, энергичных и смелых ополченцев. В случае возникновения боевых действий начальникам гарнизонов вооружить полки и батальоны стрелковым оружием, снабдить боеприпасами и использовать по своему усмотрению, исходя из обстановки.

Начальник артиллерийского снабжения СКВО обязывался создать в каждом гарнизоне края при одной из войсковых частей запас стрелкового вооружения и боеприпасов из расчета: на каждый полк 1 ооо винтовок, 30 ручных пулеметов, на отдельный батальон 500 винтовок, 15 ручных пулеметов, патронов на каждую винтовку по 60 штук (ЦДНИКК. Ф. 1774-А. Оп. 2. Д. 277. Л. 20).

На состоявшемся 6 августа 1941 г. в рабочем поселке Адлер партийном бюро района было решено ввести в состав штаба народного ополчения председателя районного совета Осоавиахима П.А. Щербину, члена ВКП(б) с 1939 г., вместо Колошейнова, которого призвали в ряды РККА. Командиром батальона народного ополчения был утвержден А.П. Федоровский, член ВКП(б) с 1939 г., начальником штаба народного ополчения А.Н. Шатских, член ВКП(б) с 1940 г. О принятых решениях был уведомлен крайком ВКП(б) с просьбой утвердить в должности командира отряда Федоровского и комиссара Шатских (ЦДНИКК. Ф. 508. Оп. 1. Д. 66. Л. 66-68).

6 августа 1941 г. был утвержден краевой штаб народного ополчения. Его начальником был избран председатель краевого совета Осоавиахима А.М. Янин, комиссаром - третий секретарь крайкома ВКП(б) В.А. Родионов, в состав штаба вошли заместитель председателя крайисполкома 14 Ф.А. Васильев, военный комиссар края А.И. Котелкин, начальник гарнизона Краснодарского края и города Краснодара К.Н. Степанов. Кроме этого, было утверждено положение о краевом штабе народного ополчения, которому поручалось к 10 августа 1941 г. разработать и утвердить положения о штабах народного ополчения городов и районов Краснодарского края (ЦДНИКК. Ф. 1774-А. Оп. 2. Д. 277. Л. 1).

В соответствии с положением о краевом штабе народного ополчения штаб являлся руководящим центром народного ополчения в крае и в своей деятельности был подотчетен крайкому ВКП(б) и крайисполкому. В обязанности штаба входило:

a) руководство работой штабов народного ополчения районов и городов;

б) общее руководство и контроль за ходом формирования, обучения и снабжения подразделений народного ополчения;

в) оказание практической помощи в разрешении всех вопросов, касающихся организации и обучения подразделений народного ополчения;

г) проверка состояния подразделений народного ополчения, хода и постановки военного обучения;

14 Крайисполком - Краснодарский исполнительный комитет Совета депутатов трудящихся. 
д) привлечение в нужных случаях для организации нормальной учебы в подразделениях командиров частей РККА и ВМФㄹ, а также специалистов из Осоавиахима, СОКК и КП ${ }^{16}$, физкультуры и профсоюзов;

е) представление крайкому ВКП(б) и крайисполкому предложений организационного порядка, по вопросам снабжения подразделений народного ополчения учебными пособиями, боевым снаряжением и другими материалами;

ж) представление на утверждение крайкома ВКП(б) командиров и комиссаров полков и батальонов народного ополчения (ЦДНИКК. Ф. 1774-А. Оп. 2. Д. 277. Л. 2-3).

Положение о городском, районном штабе народного ополчения было утверждено краевым штабом народного ополчения 9 августа 1941 г. Для руководства и обучения ополченцев в Сочи был создан штаб отряда народного ополчения в составе секретаря горкома ВКП(б), председателя горисполкома ${ }^{17}$, председателя городского совета Осоавиахима, военного комиссара города, начальника гарнизона и начальника городского отдела НКВД. Штаб являлся руководящим органом народного ополчения в городе и в своей деятельности был подотчетен горкому ВКП(б) и горисполкому. В обязанности штаба входило:

а) оказание практической помощи руководителям предприятий и учреждений в деле формирования подразделений народного ополчения и организации военного обучения; б) контроль за состоянием военного обучения и снабжением подразделений народного ополчения;

в) разработка планов и предложений проведения тактических учений подразделений народного ополчения, привлекая для этой цели командиров РККА, командиров запаса и работников общественных организаций Осоавиахима, СОКК и КП, физкультуры и профсоюзов;

г) распределение имеющихся в наличии учебно-наглядных пособий для подразделений народного ополчения и организация работы по изготовлению учебных пособий на месте;

д) определение и организация охраны государственных объектов, социалистической собственности и оказание помощи истребительным батальонам, привлекая для этого подразделения народного ополчения;

е) проверка личного состава подразделений народного ополчения;

ж) утверждение командно-политического состава подразделений народного ополчения (командира, политрука) и представление на утверждение в краевой штаб народного ополчения кандидатов на должности командиров и комиссаров батальонов и полков;

3) представление горкому ВКП(б) и горисполкому предложений по вопросам организационного порядка и снабжения подразделений народного ополчения учебными пособиями, боевым снаряжением, конским составом и другими материалами.

Помимо этого, городскому штабу народного ополчения предоставлялась возможность давать рекомендации и указания руководителям предприятий, учреждений и других организаций по вопросам формирования подразделений народного ополчения, военного обучения и требовать от руководителей выполнения этих рекомендаций и указаний (ЦДНИКК. Ф. 1774-А. Оп. 2. Д. 277. Л. 4-5).

Решением бюро горкома ВКП(б) утверждались начальник городского штаба народного ополчения - председатель городского совета Осоавиахима и комиссар штаба народного ополчения - секретарь горкома ВКП(б). Подразделения народного ополчения создавались по организационной структуре частей РККА - отделение, взвод, рота, батальон и полк (ЦДНИКК. Ф. 1774-А. Оп. 2. Д. 277. Л. 4-6).

В формировании народного ополчения активно участвовали комсомольцы Краснодарского края. В Сочи вступило в ополчение 2200 человек, т.е. 70 \% от всей комсомольской организации, в Краснодаре - 2764 человека. Боевые кадры для народного ополчения дали практически все предприятия, учреждения и учебные заведения края.

\footnotetext{
15 ВМФ - Военно-морской флот.

16 СОКК и КП - Союз обществ Красного Креста и Красного Полумесяца.

17 Горисполком - Сочинский исполнительный комитет Совета депутатов трудящихся.
} 
В Шапсугском районе отряд народного ополчения не был создан, в 39 группах самозащиты занимались 624 комсомольца. Комсомольцы с. Лазаревское активно участвовали в строительстве береговых укреплений, в течение 10 дней в числе других работали 70 комсомольцев, из которых районная партийная организация выделила В. Романову, О. Струговщикову, М. Гробирович и др. При Сочинском городском комитете ВЛКСМ ${ }^{18}$ был организован комсомольский батальон, в котором проводились занятия по изучению военного дела с учетом военной дисциплины. Помимо этого, в Сочи было организовано 4 комсомольских санитарных дружины с охватом более 200 человек и подобрано 216 доноров для сдачи крови. По Краснодарскому краю для подготовки необходимо было привлечь 16 ооо инструкторов противовоздушной и химической обороны и 30 ооо начальствующего состава групп самозащиты, в Сочи эти показатели составляли $42 \%$ (ЦДНИКК. Ф. 1774-А. Оп. 2. Д. 277. Л. 12-16).

В августе 1941 г. первые секретари городов и районов края получили предписание для руководства и исполнения, в котором предлагалось в соответствии с положением о штабах народного ополчения утвердить командиров и политработников подразделений не позднее 15 августа 1941 г.

Кроме того, первые секретари городов и районов края обязывались обеспечить явку к 9 часам 17 августа 1941 г. на совещание в Краснодар (краевой совет Осоавиахима) начальников штабов народного ополчения городов и районов для получения подробных указаний. Им необходимо было иметь при себе следующие данные: а) численный состав народного ополчения, из них: коммунистов, комсомольцев и женщин; б) количество сформированных в городе, районе отделений, взводов и рот народного ополчения и укомплектованность командно-политическим составом. При этом из штаба краевого ополчения препровождались положение о городском, районном штабе народного ополчения, а также схема с численным составом подразделений народного ополчения (отделение, взвод, рота), в соответствии с которой следовало создавать подразделения (ЦДНИКК. Ф. 1774-А. Оп. 2. Д. 277. Л. 30-31).

Вышеуказанная схема предусматривала структуру и численный состав стрелковой роты народного ополчения:

- отделение состоит из командира, наблюдателя-дальномерщика, наводчикапулеметчика, помощника наводчика, гранатометчика, помощника гранатометчика и стрелков в количестве от 6 до 9 человек;

- взвод состоит из командира, помощника командира, четырех отделений по 15 человек;

- рота состоит из командира, политрука, старшины, помощника командира, писаря, лекаря, трех стрелковых взводов и пулеметного взвода в количестве 30 человек.

В соответствии с указанной схемой стрелковая рота состояла, по нашим подсчетам, из 220 человек. В примечании указывалось, что стрелковая рота по численному составу может быть доведена до 250 человек за счет увеличения числа стрелков в отделениях (ЦДНИКК. Ф. 1774-А. Оп. 2. Д. 277. Л. 7).

На основании приказа № 3 от 14 августа 1941 г. в состав отряда народного ополчения города Сочи была включена рота № 4, сформированная из восьми колхозов Навагинского сельского совета (им. Сталина, им. ОГПУ, им. Микояна, им. Шаумяна, им. Красина, им. Горького, им. Ворошилова и им. III-го Интернационала). Рота состояла из трех взводов, состоящих из 4 отделений по 18 человек, кавалерийского взвода в количестве 26 человек и командно-административного состава. Всего в роте № 4 насчитывалось 308 человек. Ее командиром был утвержден А.А. Нагабедьян, политруком С.К. Аракельян, старшиной А.Г. Кочконьян, а также были назначены командиры взводов и отделений (ЦДНИКК. Ф. 558. Оп. 1. Д. 135. Л. 7-7об.).

Командиром отряда народного ополчения У.В. Стояновым было приказано А.А. Нагабедьяну укомплектовать роту к 1 сентября 1941 г. и немедленно приступить к военному обучению ополченцев. Разрешалось комплектование до полного штата производить за счет женщин-одиночек, добровольно записавшихся в народное ополчение. Помощнику командира отряда народного ополчения Аксенову приказывалось обеспечить

18 ВЛКСМ - Всесоюзный ленинский коммунистический союз молодежи. 
роту необходимыми пособиями, а также учебным оружием. Начальнику штаба Музыкину необходимо было контролировать комплектование роты и через службу штаба оказывать Нагабедьяну всестороннюю помощь (ЦДНИКК. Ф. 558. Оп. 1. Д. 135. Л. 7об.).

Краевой штаб народного ополчения 22 августа 1941 г. предложил начальникам и комиссарам городских и районных штабов народного ополчения проверить весь личный состав бойцов в подразделениях и отчислить лиц, социально-чуждых и морально неустойчивых, бывших кулаков, судимых за грабежи и т.д. Их отчисление необходимо было проводить под видом возрастного несоответствия и по состоянию здоровья.

Всех женщин, желающих вступить в ряды народного ополчения, как правило, предлагалось принимать в нестроевые подразделения, а уже зачисленных ополченцами перевести из строевых подразделений в группы и команды ПВХО ${ }^{19}$, санитарные дружины и т.д. В тех случаях, когда женщины по физическому состоянию здоровья смогут нести строевую службу и будут настаивать на оставлении их в строю, необходимо удовлетворять их желание и зачислять в строевые подразделения.

В процессе военного обучения ознакомить личный состав бойцов народного ополчения с правилами изготовления и метания бутылок с горючим по танкам, танкеткам, бронемашинам и автомашинам. Из наиболее смелых и решительных, хорошо натренированных бойцов в метании бутылок в цель создать в каждом отделении группу истребителей танков, состоящую из 2-3 человек. Краевым штабом во все подразделения была направлена инструкция по подготовке бойцов и групп истребителей автомотомехсредств противника (танков, танкеток и автобронемашин).

Кроме этого, необходимо было к 1 сентября 1941 г. представить в краевой штаб народного ополчения предложения о создании в городах и районах батальонов и полков, в них указать подразделения, которые должны войти в состав батальона, полка (предприятия, учреждения, совхоза, колхоза и машинотракторной станции). Сообщить территориальное расположение подразделений (станица, поселок, хутор) и постоянное место работы командиров и комиссаров батальонов, полков. Также указывалось, что батальоны и полки народного ополчения, сформированные по указанию штаба СКВО, а также кавалерийские сотни, созданные по указанию крайкома ВКП(б), входят в состав народного ополчения и подчиняются городским и районным штабам народного ополчения (ЦДНИКК. Ф. 1774-А. Оп. 2. Д. 277. Л. 32-320б.).

На основании приказа № 5 от 23 августа 1941 г. в сочинском отряде народного ополчения состоялись следующие назначения: командир взвода МТО Ф.Д. Марущак, командир 4-й роты П.К. Медзелец, помощник командира 4-й роты В.В. Ведищев, связной при штабе полка Э.П. Дубровский, командир взвода саперов И.Г. Жук, командир 2-й роты Ф.Л. Рехтюк и писарь штаба Н.В. Клещинов. В состав отряда вошло 24 работника молкомбината и 12 человек с нефтебазы, которых объединили в один взвод под командованием С.А. Рафаэлова. Из женщин молкомбината и нефтебазы было решено создать стрелковое отделение (ЦДНИКК . Ф. 558. Оп. 1. Д. 135. Л. 8-8об.).

По состоянию на 25 августа 1941 г. по Краснодарскому краю записалось в народное ополчение 224097 человек, в том числе: 18238 членов и кандидатов ВКП(б), 19033 комсомольца, 56460 женщин. Занятия по военному обучению посещали 159685 человек, в том числе 12276 членов и кандидатов ВКП(б), 14699 комсомольцев, 42301 женщина. Было сформировано 27 казачьих кавалерийских сотен в составе 3386 человек, сотни были укомплектованы преимущественно людьми, знающими кавалерийское дело, при этом не хватало седел и клинков ( ЦДНИКК. Ф. 1774-А. Оп. 2. Д. 277. Л. 34).

На заседании краевого штаба народного ополчения 29 августа 1941 г. утвердили командиром сочинского полка народного ополчения Стоянова Устина Васильевича, комиссаром - Архипова Александра Ивановича и комиссаром адлерского батальона Остапенко Василия Ивановича (ЦДНИКК. Ф. 1774-А. Оп. 2. Д. 277. Л. 11).

На основании рекомендаций по организации стрелковых рот, присланных из краевого штаба, в Сочи происходит реорганизация полка народного ополчения. В соответствии с приказом № 6 от 30 августа 1941 г. по отряду народного ополчения города Сочи была

19 ПВХО - противовоздушная и химическая оборона. 
объявлена схема организации отряда, в состав которого входил батальон, состоящий из трех стрелковых рот.

Стрелковое отделение состояло из командира, наблюдателя-дальномерщика, пулеметчика-наводчика, помощника пулеметчика, трех гранатометчиков по танкам, гранатометчика, помощника гранатометчика и шести бойцов-стрелков. Всего в стрелковом отделении значилось 15 человек. Стрелковый взвод (62 человека) состоял из командира, помощника командира, четырех стрелковых отделений по 15 человек каждое.

Пулеметный расчет на вьюках и двуколке состоял из начальника пулемета, наблюдателя-дальномерщика, пулеметчика-наводчика, помощника пулеметчика, двух подносчиков патронов и одного коновода. Итого в пулеметном расчете было 7 человек. В состав пулеметного взвода входило четыре пулеметных расчета, а также командир взвода и его помощник, т.е. всего 30 человек.

Стрелковая рота состояла из командира, помощника командира, политрука, врача, писаря, начальников химической службы, службы разведки и связи. В санитарной службе было 14 бойцов, в службе связи 5 человек, в химической службе и разведке по 7 человек. В службу управления роты входило 4 связных, наблюдатель и делопроизводитель. Служба тыла состояла из повара, двух каптенармусов и двух ездовых. Итого 52 человека.

Всего в состав батальона входило три роты по 268 ополченцев каждая, здесь следует добавить командира и комиссара батальона, а также адъютанта. Таким образом, сочинский батальон народного ополчения состоял из 807 человек, его формирование завершилось 2 сентября 1941 г. Командир отряда народного ополчения Стоянов назначил командиром батальона Лагутина Якова Назаровича и комиссаром батальона Комарова Александра Петровича (ЦДНИКК. Ф. 558. Оп. 1. Д. 135. Л. 9-10).

30 августа 1941 г. за подписью начальника штаба народного ополчения края председателя краевого совета Осоавиахима Янина и комиссара штаба народного ополчения края третьего секретаря крайкома ВКП(б) Родионова в города и районы края отправлено сообщение, в котором указывались итоги проверки состояния военного обучения в подразделениях народного ополчения. Установлено, что отдельные командиры при обучении ополченцев увлекаются более легкими формами обучения - маршировкой и ружейными приемами, а наиболее важные и неотложные предметы специальной подготовки не применяют. Поэтому краевой штаб предлагал военное обучение в подразделениях народного ополчения проводить в соответствии с программой «Ворошиловский стрелок» 1 ступени (военного времени), сосредоточив основное внимание на следующем:

а) знать в совершенстве механизм винтовки, пулемета и гранаты, уметь точно и без промаха стрелять и метать гранату;

б) изготавливать и метать бутылки с горючей смесью;

в) в совершенстве овладеть штыковым боем и боем малой лопатой;

г) уметь отрывать все виды окопов как для одиночного бойца, так и отделения;

д) правильно вести разведку и особенно ночные поиски;

е) уметь вести наблюдение за противником, правильно делать перебежки, уметь маскироваться, используя складки местности и местные предметы, и нести службу связного;

ж) уметь преодолевать все виды препятствий и водных преград;

з) совершать марши по дорогам и пересеченной местности без дорог до 25 км в составе отделения, взвода и роты;

и) уметь ориентироваться по солнцу, звездам и местным предметам;

к) уметь вести бой в обороне, наступательном бою, при атаке и борьбе внутри обороны противника;

л) правильно вести борьбу с авиадесантами противника и т.д. (ЦДНИКК. Ф. 1774-А. Оп. 2. Д. 277. Л. 33-33об.).

Также предлагалось занятия проводить в полевых условиях, в составе отделения, взвода и роты, используя рельеф местности и местные предметы, как днем, так и ночью, независимо от погоды. В целях упорядочения и правильной постановки военного обучения в подразделениях народного ополчения необходимо было провести инструктивнометодическое совещание командиров и политруков рот, пригласив на него в качестве докладчиков кадровых командиров РККА или командиров запаса, знакомых с военным 
делом. О принятых мерах необходимо было доложить 10 сентября 1941 г. (ЦДНИКК. Ф. 1774А. Оп. 2. Д. 277. Л. 33об.).

На основании приказа № 7 от 1 сентября 1941 г. по штабу народного ополчения города Сочи в первой, второй и третьей ротах первого батальона были утверждены командиры рот, взводов, отделений, а также назначены политруки и командно-административный состав (ЦДНИКК. Ф. 558. Оп. 1. Д. 135. Л. 20-20об.).

В сентябре 1941 г. сочинский отряд народного ополчения получил на боевое вооружение гладкоствольное оружие, которое силами ополченцев было отремонтировано и приведено в полный боевой порядок. Все оружие было пристрелено бойцами и закреплено за ними. Отряд располагал 220 исправными гладкоствольными ружьями, из которых 160 двуствольных, 60 одноствольных и несколько мелкокалиберных винтовок. Заряженных патронов к ним имелось 12 ооо шт., а также было в наличие 100 кг пороха, 17 ооо пуль и 90 ооо капсюлей. Указанного количества оружия для нужд отряда народного ополчения было недостаточно. Поэтому планировалось приобрести учебное оружие: станковый пулемет, миномет, пулемет-автомат, состоящий на вооружении у германской армии, гранаты $\Phi-1$ и РПГ образца 1941 г., а также 20 боевых винтовок для проведения подготовительных и боевых стрельб в полевых условиях (ЦДНИКК. Ф. 558. Оп. 1. Д. 161. Л. 6).

По состоянию на 1 сентября 1941 г. в народном ополчении Адлерского района числилось 1865 человек, 70 \% которых посещали занятия по обучению военному делу. Партийными работниками района было решено уделить больше внимания дисциплине, боевой и политической подготовке ополченцев, для чего проводить лекции и организовать выпуск стенгазеты (ЦДНИКК. Ф. 508. Оп. 1. Д. 67. Л. 11-12).

К 1 октября 1941 г. в отряд народного ополчения от Осоавиахима поступила программа подготовки на знак «Ворошиловский стрелок» 1 ступени военного времени. На основании указания штаба городского формирования народного ополчения командование отряда пересмотрело учебу и план занятий с учетом требований полученной программы. Для занятий по военным предметам с бойцами и командно-политическим составом по программе составлялись для рот и взводов расписания занятий со ссылкой на учебные пособия, которых в отряде имелось в достаточном количестве.

К занятиям по военному делу с бойцами командный состав готовился по утвержденному расписанию занятий. Командиры взводов составляли конспекты, которые проверялись и утверждались командирами рот. На занятия с командно-политическим составом привлекался кадровый - начальствующий состав, прибывающий с фронта, и командированные инструкторы Осоавиахима и городского военкомата. Занятия по специальным предметам проводились по программам и расписаниям занятий, составленным начальниками служб по специальности (ЦДНИКК. Ф. 558. Оп. 1. Д. 161. Л. 2-3).

В течение 1941 г. из личного состава сочинского народного ополчения постоянно шел отток бойцов, командиров и политработников. Руководствуясь указанием краевого и городского штабов формирования, в октябре 1941 г. полк был переформирован в батальон 3-ротного состава, химической, санитарной и служб связи, автоколонны с подчинением командиров рот непосредственному командиру и комиссару отряда народного ополчения (ЦДНИКК. Ф. 558. Оп. 1. Д. 161. Л. 5).

В отряде народного ополчения 3 октября 1941 г. были проведены учения. Легенда учений была следующая: по сведениям советской разведки, группа немецких диверсантов в составе двух отделений планирует высадку на берегу моря в районе пансионата «Кавказская Ривьера». Цель диверсантов - взорвать хлебозавод, виадук и электростанцию ( ЦДНИКК. Ф.558. Оп. 1. Д. 135. Л. 240б.). С поставленными задачами по уничтожению группы диверсантов ополченцы справились достойно.

По состоянию на 5 октября 1941 г. в сочинском батальоне народного ополчения значилось 673 человек, из которых 76 женщин, 95 членов ВКП(б), 111 членов ВЛКСМ и бойцы истребительного батальона в количестве 71 человека (ЦДНИКК. Ф. 558. Оп. 1. Д. 135. Л. 27).

На заседании горисполкома 18 октября 1941 г. было решено изъять из магазина «Динамо» для вооружения сочинского отряда народного ополчения оружие, боеприпасы и принадлежности: 42 штуки ружей и винтовок разных калибров, 5713 патронов Коровина, 8 коробок пыжей, 1 ооо пыжей войлочных, 3600 гильз металлических, 44 патронташа, 10 полевых сумок, 54 деревянных шомпола, 12 высечек, 108 экстракторов, 5 шомполов, 
39 барклаев, 46 обжимов, 14 мерок, 59 щеток для чистки оружия, 2 шлема, 298 коробок с ружейной мазью (МКУ «Архив г. Сочи». Ф. Р-137. Оп. 1. Д. 244. Л. 73).

20 октября 1941 г. прошло заседание 12-го пленума Адлерского райкома ВКП(б), на котором было отмечено, что в каждом совхозе района имеется отряд народного ополчения. Решением пленума всех секретарей первичных партийных организаций обязывали укреплять работу по военному обучению в подразделениях народного ополчения, кружках МПВО 20 и группах самозащиты (ЦДНИКК. Ф. 508. Оп. 1. Д. 63. Л. 35-43).

На заседании штаба сочинского отряда народного ополчения, состоявшемся 21 октября 1941 г., присутствовали начальник штаба формирования отряда народного ополчения председатель горисполкома А.Ф. Белоус и комиссар штаба формирования отряда секретарь горкома ВКП(б) по кадрам Шулятьев. Было решено с 30 октября 1941 г. перевести 100 ополченцев на казарменное положение для несения караульной и постовой службы, а также сформировать к 28 октября в Хосте и Навагинском сельсовете роты народного ополчения. Разрешить командиру Стоянову и комиссару Н. Белька выехать 23 октября для получения 20 ооо гильз разного калибра. Постановили назначить командиром 2-й роты В.В. Савина, заместителем командира - В.М. Мишталь-Виноградова, инструктором отряда по политической пропаганде И.Г. Моисеева (ЦДНИКК. Ф. 558. Оп. 1. Д. 135. Л. 29).

В карауле № 1 имелось 7 постов, из которых 3 поста трехсменных для охраны склада боеприпасов отряда, оружейной мастерской, штаба отряда и штаба МПВО и 4 поста двухсменных для патрулирования по городу, охраны мостов, виадуков и других объектов, закрепленных городским отделом НКВД за отрядом народного ополчения. Караул № 2 (железная дорога) располагал одним трехсменным постом для охраны оружия, четырьмя двухсменными постами патрулей для обхода железнодорожных путей, охраны пакгаузов, нефтехранилищ и других станционных сооружений. Всего для караульной и патрульной службы ежедневно назначалось 44 человека и дежурная часть в составе взвода из 66 человек (ЦДНИКК. Ф. 558. Оп. 1. Д. 161. Л. 4; ЦДНИКК. Ф. 558. Оп. 1. Д. 162. Л. 1-2).

В связи с переводом на казарменное положение отряда народного ополчения уполномоченному госпиталями системы Всесоюзного центрального совета профессиональных союзов Федосееву было предложено горисполкомом выдать во временное пользование штабу отряда казарменный инвентарь: 65 подушек, 130 наволочек, 130 простыней, 50 одеял, 20 матрацев, 20 коек (МКУ «Архив г. Сочи». Ф. Р-137. Оп. 1. Д. 244. Л. 86).

На основании постановления краевого комитета ВКП(б) от 30 октября 1941 г. был ликвидирован краевой штаб народного ополчения. Подразделения отрядов народного ополчения стали подчиняться созданным в крае городским комитетам обороны (Кубань..., 2000: 43). В Сочи и Адлерском районе во главе отрядов стояли партийные организации.

В Адлерском районе 6 ноября 1941 г. состоялся 13-й пленум райкома ВКП(б), на котором комиссар батальона народного ополчения, он же заведующий райторготделом Остапенко заявил самоотвод, т.к. он к военному делу не подготовлен, и предложил на эту должность привлечь военного специалиста. Партийный работник Новоструев отметил, что часто были случаи, когда бойцы народного ополчения переводились в истребительный батальон, не сообщив об этом командованию ополчения. Новоструев полагал, что молодые ополченцы уходят в истребительный батальон, т.к. там при обучении дают оружие, и что районный военкомат должен взять инициативу по укреплению народного ополчения. Член партийного бюро Захарьян указал, что из бойцов народного ополчения был укомплектован адлерский истребительный батальон (ЦДНИКК. Ф. 508. Оп. 1. Д. 63. Л. 58).

По состоянию на 12 ноября 1941 г. отряд сочинского народного ополчения состоял из 3 рот. Всего в нем числилось 314 человек, из которых на казарменном положении находился 161 ополченец. Первая рота состояла из 153 человек; вторая - из 128, 107 из которых находились на казарменном положении; в третьей роте значилось 146 ополченцев, 54 человека из них были на казарменном положении. Из политического донесения комиссара отряда Белька секретарю горкома ВКП(б) Шулятьеву известно, что начальник и комиссар госпиталя РККА, директор дома отдыха НКВД, начальник госпиталя (санаторий имени Фабрициуса) и другие руководители городских предприятий и учреждений

${ }_{20}$ МПВО - местная противовоздушная оборона. 
запретили ополченцам являться на дежурство по вызову командования. Кроме того, некоторые ополченцы не являлись на занятия (ЦДНИКК. Ф. 558. Оп. 1. Д. 135. Л. 34).

На основании приказа № 21 от 25 ноября 1941 г. личный состав сочинского отряда народного ополчения был полностью переведен на казарменное положение (ЦДНИКК. Ф. 558. Оп. 1. Д. 135. Л. 40).

За время обучения с июля по 25 ноября 1941 г. отряд народного ополчения готовил бойцов, командно-политический состав, передавал их по мобилизации в ряды РККА и другие военизированные организации. В результате этого в указанный период из ополчения призвано в РККА 1433 человека, передано в истребительный батальон - 76, освобождено по болезни и другим уважительным причинам - 78. Всего из ополчения выбыло 1587 человек.

Ополченцы в количестве 950 человек в составе отделения, взвода изучили учебную программу одиночно-стрелковой, стрелково-тактической подготовки, на оценки «хорошо» и «отлично». Также были проведены стрельбы из мелкокалиберных винтовок и боевые стрельбы из ружей с расстояний на 50-70 и 100 метров. Полностью пройдена программа по самоокапыванию лежа.

Учебную программу 637 ополченцев усвоили на 75 \%. Были изучены материальные и боевые свойства винтовки, пулемета и гранат. Бойцы прошли строевую одиночную подготовку без оружия, с оружием и походные расчлененные построения - отделения, взвода и роты. Пройдена программа штыкового боя и метания гранат, проведена стрельба из мелкокалиберной винтовки. Более половины бойцов получили зачет по программе «Ворошиловский стрелок» 1 ступени.

Изучение стрелкового и тактического дела имело положительные результаты в бою против немецких захватчиков. Бойцы народного ополчения присылали с фронта благодарности командно-политическому составу отряда за обучение их военному делу, особенно в стрельбе, самоокапывании и маскировке (ЦДНИКК. Ф. 558. Оп. 1. Д. 161. Л. 2).

В соответствии с приказом № 22 от 29 ноября 1941 г. по отряду народного ополчения города Сочи были упразднены должности командира, комиссара и адъютанта 1-го стрелкового батальона, командование которым принял на себя командир отряда Стоянов. В связи с этим произошли кадровые перестановки: начальником штаба вместо М.M. Музыкина, выбывшего в РККА, был назначен командир 2-й роты В.В. Савин. Командиром 2й роты был назначен Я.Н. Лагутин, его помощником - Л.З. Гершун вместо В.М. МиштальВиноградова как не справившегося с возложенными на него обязанностями. Командиром взвода службы штаба отряда по строевой части был назначен Ф.Л. Рехтюк.

Службы штаба отряда (связи, химическая, санитарная, эвакуационная, материальнотехнического обеспечения, автомотоколонна) были сведены в отдельный взвод при штабе отряда в составе отделений: связи, химслужбы, санитарной службы и автомотоотделения (ЦДНИКК. Ф. 558. Оп. 1. Д. 135. Л. 36).

Этим приказом старший врач отряда А.М. Трушкин обязывался произвести профилактические прививки (противостолбнячные, противобрюшные) всему личному составу отряда народного ополчения с 1 по 11 декабря 1941 г. Командиры рот и начальники служб были обязаны обеспечить 100 \% охват прививкой бойцов своих подразделений (ЦДНИКК. Ф. 558. Оп. 1. Д. 135. Л. 36об.).

На основании приказа № 25 от 5 декабря 1941 г. вместо начальника автоколонны И.С. Брызгалина, выбывшего в РККА, был назначен военный инженер С.И. Попов (ЦДНИКК. Ф. 558. Оп. 1. Д. 135. Л. 39).

В декабре 1941 г. отряд народного ополчения города Сочи получил очередное пополнение. В связи с этим командир отряда Стоянов приказал в воскресенье 14 декабря 1941 г. с 9 часов утра провести принятие присяги всем личным составом отряда народного ополчения в кабинете командира отряда, железнодорожном клубе и клубе медсантруда (ЦДНИКК. Ф. 558. Оп. 1. Д. 135. Л. 40об.).

Показателем высокого морального и политического состояния являлась хорошая дисциплина, которую показали Шпак (70 лет, пенсионер), токарь электростанции Туренок, учитель школы № 72 Заболотский, сотрудница дома отдыха НКВД Шрамкова и многие другие, несмотря на трудности, сознательно и без единого замечания в любую погоду несшие караульно-патрульную службу по городу. Введенные в отряде поощрения (премия, награды) еще больше поднимали моральное и политическое состояние бойцов. Приказом 
командования отряда за добросовестное отношение к службе были награждены бойцы Шпак, Ващенко, Туренок и др. (ЦДНИКК. Ф. 558. Оп. 1. Д. 161. Л. 9).

Особое внимание уделялось в отряде народного ополчения политико-воспитательному состоянию бойцов, за которым следили комиссар отряда, инструктор политической пропаганды и четыре политрука. Кроме этого, политическую агитацию проводили так называемые чтецы и беседчики, редакторы боевых листков в количестве 4 человек, которые составляли отдел агитации и политической пропаганды (ЦДНИКК. Ф. 558. Оп. 1. Д. 161. Л. 8).

С октября 1941 г. по январь 1942 г. отделом агитации и пропаганды были прочитаны лекции о международном положении «Коалиция трех Великих держав». В отряде народного ополчения ежедневно проводился политчас политруками, которые составляли тематический план, по нему проводились беседы с бойцами по различным политическим вопросам, воспитывающие в ополченцах патриотизм (ЦДНИКК. Ф. 558. Оп. 1. Д. 161. Л. 9-10).

Ежедневно чтецы и беседчики проводили беседы по вопросам текущей внутренней и внешней политики государства. С декабря 1941 г. во всех ротах и службах отряда народного ополчения выходили «Боевые листки». Политико-массовая работа в отряде народного ополчения проводилась на основании организованного социалистического соревнования между ротами и бойцами подразделений, которым были охвачены практически все бойцы. Для поднятия общего кругозора ополченцев проводились лекции научно-популярного характера, в том числе - об анатомии и физиологии человека, переливании крови и др. (ЦДНИКК. Ф. 558. Оп. 1. Д. 161. Л. 10).

С начала занятий, т.е. с 14 июля 1941 г., по 1 января 1942 г. через горком ВКП(б) и штаб формирования в отряд народного ополчения дополнительно было направлено вновь поступивших 667 ополченцев. В этот период в сочинском отряде обучалось военноспециальному делу 2006 человек. Систематически происходило убытие ополченцев, командиров и политработников в РККА, в истребительный батальон и по состоянию здоровья, что составило 1587 человек. В отряде народного ополчения на 1 января 1942 г. значилось 419 человек, из которых 114 членов и кандидатов ВКП(б), 54 члена ВЛКСМ, 245 рабочих, 152 служащих, 12 колхозников и беспартийных 251 человек (ЦДНИКК. Ф. 558. Оп. 1. Д. 161. Л. 5-6).

С 14 июля 1941 г. по 1 января 1942 г. в отряде народного ополчения прошли обучение бойцы и командиры, которые получили военную подготовку по следующим специальностям: «Ворошиловский стрелок» 1 ступени - 1212 человек, 243 пулеметчика ручного пулемета, 108 пулеметчиков станкового пулемета, 1510 метателей по танкам бутылочных гранат, 243 истребителя танков, 38 связистов, 25 химразведчиков, 40 санитаров (ЦДНИКК. Ф. 558. Оп. 1. Д. 161. Л. 3).

К 1 января 1942 г. подготовка по программе «Ворошиловский стрелок» военного времени 1 ступени была закончена. На основании распоряжения штаба формирования по пройденной программе в отряде были проведены зачеты с целью проверки усвоения бойцами и командирами военно-специальных знаний. Одновременно устранялись допущенные ошибки в учебе. Руководствуясь зачетными данными, военные комиссариаты имели возможность правильно аттестовать бойцов и командиров народного ополчения при призыве их в РККА на соответствующие должности. Планировалось провести зачеты по программе к 1 февраля 1942 г., а с вновь прибывшим пополнением бойцов - к 1 марта 1942 г. Занятия с бойцами в отряде народного ополчения проводились через день по четным числам, а с командным составом - по нечетным с 18 до 20 часов (ЦДНИКК. Ф. 558. Оп. 1. Д. 161. Л. 3).

В декабре 1941 г. в отрядах народного ополчения Краснодарского края насчитывалось 224 тысячи ополченцев, которые в дальнейшем были мобилизованы в РККА, переведены в истребительные батальоны и отряды МПВО и ПВХО (Киселев, 2017: 42).

В апреле 1942 г. в Краснодарском крае приступили к проведению посевных работ. Кроме этого, в связи с тем, что миновала опасность непосредственного вторжения на территорию края войск вермахта, внимание партийных и советских организаций к работе и боевой готовности военизированных формирований ухудшилось и послужило причиной порождения в ряде районов демобилизационных настроений (Кубань..., 2000: 236).

В мае 1942 г. командиром соичинского тряда народного ополчения являлся Я.Н. Лагутин и комиссаром Н. Белька. Весной и летом 1942 г. из отряда народного ополчения систематически 
происходило убытие личного состава в РККА, НКВД, истребительный батальон, МПВО и т.д. Отсутствуют сведения о проведении занятий по специальной и военной подготовке среди бойцов ополчения (ЦДНИКК. Ф. 558. Оп. 1. Д. 162. Л. 8-8об., 10-11).

На заседании горисполкома 16 июля 1942 г. было решено изъять из ведения отряда народного ополчения 2 комнаты с верандой в школе № 5 и предоставить их для размещения службы и личного состава 3-го отдельного батальона воздушного наблюдения, оповещения и связи (МКУ «Архив г. Сочи». Ф. Р-137. Оп. 1. Д. 251. Л. 68).

По состоянию на 10 августа 1942 г. в отряде народного ополчения состояло 215 человек, из которых 152 мужчины и 63 женщины, в том числе 53 члена и кандидата ВКП(б), 11 членов ВЛКСМ. Отряд имел на вооружении 317 единиц одноствольного и двуствольного оружия разного калибра, 30 мелкокалиберных винтовок, 12405 боевых патронов, 245 патронташей и 200 шанцевых лопат (ЦДНИКК. Ф. 558. Оп. 1. Д. 162. Л. 12-13).

В августе 1942 г. личный состав ополчения, а также имеющееся имущество и вооружение были переданы в ведение истребительных батальонов (ЦДНИКК. Ф. 558. Оп. 1. Д. 162. Л. 11, 14).

\section{5. Заключение}

Таким образом, в двадцатых числах июня 1941 г. в городе Сочи и Адлерском районе были организованы добровольные боевые дружины, которые заменили отрядами народного ополчения Краснодарского края, созданными в июле 1941 г. для усиления частей РККА, оборонявших территорию Северного Кавказа от возможного вторжения войск гитлеровской коалиции. Деятельностью отрядов народного ополчения Краснодарского края с августа по октябрь 1941 г. включительно руководил краевой штаб. Отряды народного ополчения были созданы при поддержке партийных органов - городских и районных комитетов ВКП(б), которые и возглавляли ополченцев. В Шапсугском районе Краснодарского края отряд народного ополчения не создавался.

Отряды народного ополчения на территории Большого Сочи функционировали с июля 1941 г. по август 1942 г. В указанный период бойцы отрядов проходили военно-специальную подготовку, несли караульную службу по охране общественного порядка и стратегических объектов. Личный состав отрядов был непостоянным, т.к. физически здоровых и подготовленных бойцов систематически призывали в ряды РККА, усиливали ополченцами истребительные батальоны, отделы НКВД и МПВО. Фактически отряды народного ополчения являлись кадровым резервом РККА.

\section{Литература}

Артюхов, 1995 - Артюхов С.A. Сочи: город-госпиталь. Сочи, 1995.

Артюхов, 2000 - Артюхов C.A. Сочи в годы Великой Отечественной войны 19411945 гг. Краснодар, 2000.

Ведомости, 1941 - Ведомости Верховного Совета СССР. 1941. № 29.

Великая Отечественная..., 2020 - Великая Отечественная война в истории и памяти народов Юга России: события, участники, символы / Материалы Всероссийской научной конференции, посвященной 75-летию Победы в Великой Отечественной войне (2. Ростовна-Дону, 1O-11 сентября 2020 г.) / Отв. ред. акад. Г.Г. Матишов. Ростов-на-Дону, 2020.

Вестник архива, 2010 - Вестник архива Президента Российской Федерации. Война 1941-1945. M., 2010.

Киселев, 2017 - Киселев И.В. Испытание войной. Краснодарский край в 1941-1945 годах // Наследие веков. 2017. № 4.

Кубань..., 1965 - Документы отваги и героизма: Кубань в Великой Отечественной войне 1941-1945 гг. // Сборник документов и материалов / Сост. Е.Г. Ботина, А.П. Ботин, В.Ф. Латкин и др. Краснодар, 1965.

Кубань..., 2000 - Кубань в годы Великой Отечественной войны 1941-1945 гг.: Рассекреченные документы. Хроника событий. Книга первая 1941-1942 гг. / Отв. составители А.М. Беляев, И.Ю. Бондарь. Краснодар, 2000.

Куликов, 2009 - Куликов Н.А. Эволюция системы государственного управления в городе Сочи в период Великой Отечественной войны (1941-1945 гг.) // Бълые годы. 2009. № 4(14). 
Кучерова, 2005 - Кучерова И.Ю. К вопросу об обороне города Сочи в годы Великой Отечественной войны // История и историки в контексте времени. 2005. № 3.

Мамадалиев, 2007 - Мамадалиев A.M. Сочинское народное ополчение: формирование, структура и деятельность // Бълые годы. 2007. № 2.

МКУ «Архив г. Сочи» - Муниципальное казенное учреждение города Сочи «Сочинский городской архив».

Основные..., 1986 - Основные административно-территориальные преобразования на Кубани (1793-1985 гг.) // Сост. А.С. Азаренков, И.Ю. Бондарь, Н.С. Вертышева. Краснодар, 1986.

Солдатские мемуары..., 1998 - Солдатские мемуары сочинских ветеранов войны. Составитель Лазарев Н.А. Т. 1, 2. Сочи, 1998.

Таран, 2019 - Военно-историческое наследие города Сочи (1941-1945 гг.) // Материалы лектория / Авт. предисловия и авт.-сост. К.В. Таран. Сочи, 2019.

ЦДНИКК - Центр документации новейшей истории Краснодарского края.

Черкасов, 2008а - Черкасов А.А. Сочи в годы Великой Отечественной войны: истребительный батальон и партизанское движение // Былые годы. 2008. № 4 (10).

Черкасов, 2008b - Черкасов A.A. К некоторым аспектам работы Сочинской госпитальной базы (1941-1945 гг.): периодизация и эффективность // Былые годы. 2008. № 2 (8).

Taran, 2020 - Taran K.V. The Military Operations on the Sochi and Lazarev Directions (August 1942) // Voennyi sbornik. 8(2): 65-75.

\section{References}

Artyukhov, 1995 - Artyukhov, S.A. (1995). Sochi: gorod-gospital' [Sochi: city hospital]. Sochi. [in Russian]

Artyukhov, 2000 - Artyukhov, S.A. (2000). Sochi v gody Velikoi Otechestvennoi voiny 19411945 gg. [Sochi during the Great Patriotic War of 1941-1945]. Krasnodar. [in Russian]

Cherkasov, 2008a - Cherkasov, A.A. (2008). Sochi v gody Velikoi Otechestvennoi voiny: istrebitel'nyi batal'on i partizanskoe dvizhenie [Sochi during the Great Patriotic War: an extermination battalion and partisan movement]. Bylye gody. 4(10). [in Russian]

Cherkasov, 2008b - Cherkasov, A.A. (2008). K nekotorym aspektam raboty Sochinskoi gospital'noi bazy (1941-1945 gg.): periodizatsiya i effektivnost' [To some aspects of the work of the Sochi Hospital Base (1941-1945): periodization and efficiency]. Bylye gody. 2(8). [in Russian]

Kiselev, 2017 - Kiselev, I.V. (2017). Ispytanie voinoi. Krasnodarskii krai v 1941-1945 godakh [Trial by war. Krasnodar Kray in 1941-1945]. Nasledie vekov. 4. [in Russian]

Kuban'..., 1965 - Dokumenty otvagi i geroizma: Kuban' v Velikoi Otechestvennoi voine 19411945 gg. [Documents of courage and heroism: Kuban in the Great Patriotic War of 1941-1945]. Sbornik dokumentov i materialov. Sost. E.G. Botina, A.P. Botin, V.F. Latkin i dr. Krasnodar, 1965. [in Russian]

Kuban'..., 2000 - Kuban' v gody Velikoi Otechestvennoi voiny 1941-1945 gg.: Rassekrechennye dokumenty. Khronika sobytii. Kniga pervaya 1941-1942 gg. [Kuban during the Great Patriotic War 1941-1945: Declassified documents. Chronicle of events. The first book, 1941-1942]. Otv. sostaviteli A.M. Belyaev, I.Yu. Bondar'. Krasnodar, 2000. [in Russian]

Kucherova, 2005 - Kucherova, I.Yu. (2005). K voprosu ob oborone goroda Sochi v gody Velikoi Otechestvennoi voiny [To the issue of the defense of the city of Sochi during the Great Patriotic War]. Istoriya i istoriki $v$ kontekste vremeni. 3. [in Russian]

Kulikov, 2009 - Kulikov, N.A. (2009). Evolyutsiya sistemy gosudarstvennogo upravleniya v gorode Sochi v period Velikoi Otechestvennoi voiny (1941-1945 gg.) [The evolution of the public administration system in the city of Sochi during the Great Patriotic War (1941-1945)]. Bylye gody. 4(14). [in Russian]

Mamadaliev, 2007 - Mamadaliev, A.M. (2007). Sochinskoe narodnoe opolchenie: formirovanie, struktura i deyatel'nost' [Sochi people's militia: formation, structure and activity]. Bylye gody. 2. [in Russian]

MKU «Arkhiv g. Sochi» - Munitsipal'noe kazennoe uchrezhdenie goroda Sochi «Sochinskii gorodskoi arkhiv» [Municipal government institution of the city of Sochi "Sochi City Archive"]. [in Russian] 
Osnovnye..., 1986 - Osnovnye administrativno-territorial'nye preobrazovaniya na Kubani (1793-1985 gg.) [Basic administrative and territorial transformations in the Kuban (1793-1985)]. Sost. A.S. Azarenkov, I.Yu. Bondar', N.S. Vertysheva. Krasnodar, 1986. [in Russian]

Soldatskie memuary..., 1998 - Soldatskie memuary sochinskikh veteranov voiny [Soldiers' memoirs of Sochi war veterans.]. Sostavitel' Lazarev N.A. T. 1, 2. Sochi, 1998. [in Russian]

Taran, 2019 - Voenno-istoricheskoe nasledie goroda Sochi (1941-1945 gg.) [Militaryhistorical heritage of the city of Sochi (1941-1945)]. Materialy lektoriya. Avt. predisloviya i avt.sost. K.V. Taran. Sochi, 2019. [in Russian]

Taran, 2020 - Taran, K.V. (2020). The Military Operations on the Sochi and Lazarev Directions (August 1942). Voennyi sbornik. 8(2): 65-75.

TsDNIKK - Tsentr dokumentatsii noveishei istorii Krasnodarskogo kraya [Center of Documentation of Contemporary History of Krasnodar Kray].

Vedomosti, 1941 - Vedomosti Verkhovnogo Soveta SSSR. 1941. № 29. [in Russian]

Velikaya Otechestvennaya..., 2020 - Velikaya Otechestvennaya voina v istorii i pamyati narodov Yuga Rossii: sobytiya, uchastniki, simvoly [The Great Patriotic War in the history and memory of the peoples of the South of Russia: events, participants, symbols]. Materialy Vserossiiskoi nauchnoi konferentsii, posvyashchennoi 75-letiyu Pobedy $v$ Velikoi Otechestvennoi voine (g. Rostov-na-Donu, 10-11 sentyabrya 2020 g.). Otv. red. akad. G.G. Matishov. Rostov-naDonu. [in Russian]

Vestnik arkhiva, 2010 - Vestnik arkhiva Prezidenta Rossiiskoi Federatsii. Voina 1941-1945. M., 2010. [in Russian]

\section{Отряды народного ополчения на территории Большого Сочи в годы Великой Отечественной войны (июль 1941 г. - август 1942 г.)}

Анвар Мирзахматович Мамадалиев a , b, Константин Викторович Таран ${ }^{\mathrm{a}}$, b , *

а Черкас глобальный университет, Вашингтон, США

b Волгоградский государственный университет, Волгоград, Российская Федерация

Аннотация. В данной статье рассматриваются организация и деятельность отрядов народного ополчения, созданных в июле 1941 г. на территории Большого Сочи в годы Великой Отечественной войны. Они действовали до августа 1942 г., после чего отряды ополченцев с имуществом были переданы в состав истребительных батальонов. В период деятельности в отрядах народного ополчения бойцы проходили военное обучение, несли караульно-постовую службу.

В качестве источников были использованы архивные материалы Центра документации новейшей истории Краснодарского края и МКУ «Архив г. Сочи», сборники архивных документов. Дополнительно были привлечены статьи и публикации российских исследователей, воспоминания ветеранов.

В заключении автор приходит к выводу, что деятельность отрядов народного ополчения была направлена на несение караульно-постовой службы по охране стратегических объектов. Также проводилось обучение военным и специальным дисциплинам, т.е. отряды народного ополчения являлись кадровым резервом РККА.

Ключевые слова: народное ополчение, военное обучение, горкомы и райкомы ВКП(б), горисполком.

\footnotetext{
* Корреспондирующий автор

Адреса электронной почты: taran.constantin@yandex.ru (К.В. Таран), anvarm@mail.ru (A.M. Мамадалиев)
} 